\title{
Current and emerging treatments for relapsing multiple sclerosis in Argentinian patients: a review
}

This article was published in the following Dove Press journal:

Degenerative Neurological and Neuromuscular Disease

20 June 2014

Number of times this article has been viewed

\section{Juan I Rojas \\ Liliana Patrucco \\ Edgardo Cristiano}

Multiple Sclerosis Center of Buenos Aires, Neurology Department, Hospital Italiano de Buenos Aires, Buenos Aires, Argentina
Correspondence: Juan Ignacio Rojas Multiple Sclerosis Center of Buenos Aires, Hospital Italiano de Buenos Aires, Perón 4272, CPI4II, Buenos Aires, Argentina

Tel +54 II 49590322

Fax +54 II 49590322

Email juan.rojas@hospitalitaliano.org.ar
Abstract: Multiple sclerosis (MS) is an autoimmune disease of the central nervous system. Recent developments have led to newer therapeutic options for disease treatment. A few studies have reported MS prevalence rates between 12 and 20 per 100,000 inhabitants nationwide in Argentina, and an incidence of 1.76 cases per 100,000 inhabitants per year. Considering the epidemiology of MS in Argentina, the total number of patients affected is estimated at $5,000-8,000$ patients, with nearly $55 \%-65 \%$ of patients having a relapsing-remitting MS subtype of the disease. The aim of this review is to provide an overview of current and emerging treatments available in Argentina for patients with MS.

Keywords: multiple sclerosis, Argentina, treatments, disease-modifying drugs

\section{Introduction}

Multiple sclerosis (MS) is an autoimmune disease of the central nervous system in which environmental factors act together in a genetically susceptible individual to produce the disease. ${ }^{1}$ After car accidents, the disease is the second most common cause of neurological disability, compromising the patient's quality of life, their social activities, and their environment. $^{2}$

Despite the fact that much information exists about the disease in terms of epidemiology, clinical course, prognostics, health insurance, and costs, much of this information has come from developed countries; there is scarce evidence regarding MS in developing countries from South America. ${ }^{3}$

Here, we describe aspects of MS in Argentina with regard to health insurance, regulatory agencies, and finally, the disease-modifying drugs available for treatment of the condition.

Argentina is located in the southern part of South America. With an area of $2,780,400 \mathrm{~km}^{2}$ and almost 40,000,000 inhabitants, Argentina is the eighth largest country in the world and the largest Spanish-speaking nation. ${ }^{4}$

The country has an extremely segmented health system, consisting of three large sectors: public, private, and managed care (the last two systems cover a population of nearly 18.3 million people, distributed among close to 300 entities of varying scope and size). Beneficiaries of the private system can freely choose their health maintenance organization, and ten of these organizations account for nearly $50 \%$ of the covered population. The public system covers $35 \%$ of the population and includes mainly uninsured people under Ministry of Health programs, high-cost programs with special reimbursement, and public hospitals. The private system includes almost 
$5 \%$ of the population, and the managed care system, which includes almost $60 \%$ of the population, covers employees and their families. ${ }^{5}$

In Argentina, the National Administration of Drugs, Foods, and Medical Devices is an agency created in 1992 to participate in the protection of human health by assuring the quality of the products it regulates (drugs, foodstuffs, medicinal products, diagnosis reagents, cosmetic products, dietary supplements, and household cleaning products). ${ }^{6}$ The agency's professionals and technicians perform the process of authorization, registration, standardization, vigilance, and monitoring of the products used in the human medicine, food, and cosmetics fields throughout the country. The administration's main objective is to guarantee that drugs, foodstuffs, and medical devices are compliant in terms of efficacy, safety, and quality. Its work is analogous to that of the US Food and Drug Administration in the United States or the European Medicines Agency in the European Union. ${ }^{6}$

With regard to MS disease characteristics, in Argentina, a few studies report MS prevalence rates of 12-20 per 100,000 inhabitants in the region of Buenos Aires (latitude, $\left.34^{\circ} \mathrm{S}\right) .^{3,4,7}$ The vast majority of the population in this area is of European descent (mainly Spanish and Italian), and only a minority of groups include mestizos (a Spanish term used to designate people of mixed European and Amerindian ancestry living in the region of Latin America). ${ }^{7,8}$ In a study performed in Patagonia, the southern region of the country, the prevalence reported was similar to that of Buenos Aires, with almost 17.2 patients per 100,000 inhabitants in 2002 for a total surface area of $768,165 \mathrm{~km}^{2} .{ }^{9}$ Previous studies showed that Argentina is a medium-risk area for MS. ${ }^{3}$ Only one study in the country evaluated the incidence of MS. ${ }^{10}$ The study was conducted on the population of a health maintenance organization in Buenos Aires between 1991 and 2007 and showed an incidence density of 1.76 cases per 100,000 inhabitants per year. ${ }^{10}$ Considering the epidemiology of MS in Argentina provided by previous studies, the total number of patients affected is estimated at 5,000-8,000 patients, with nearly 55\%-65\% of patients having a relapsing-remitting MS (RRMS) subtype of the disease. ${ }^{11}$ Regarding the cost of the disease in Argentina, a recent study evaluated this issue in affected patients. ${ }^{12}$ The study showed that MS imposes a significant economic burden on the Argentinean society. The mean annual cost per patient was estimated at US\$36,025 in patients with an expanded disability status scale (EDSS) between 0 and 3 and reached US\$50,712 in patients with an EDSS 7. The economic burden increases with higher physical disability. This was accounted for by the increase in resource use of medical visits, informal care, professional care, sick leave, and retirement because of MS in the analyzed sample. ${ }^{12}$ Regarding specific medications to treat MS, drugs are covered $100 \%$ on a case-by-case basis by national and provincial governments. ${ }^{5}$

This information has been compared with data from the rest of Latin America. A recent epidemiological review of the region demonstrated that the prevalence of MS ranges from 0.75 to 21.1 cases per 100,000 inhabitants, with the highest prevalence being reported in Brazil, Argentina, and Martinique of the West French Indies (15-21.1 cases per 100,000 inhabitants), whereas the lowest prevalence reported was in Colombia and Ecuador (0.75-5.05 cases per 100,000 inhabitants). ${ }^{7}$ The distribution of population genetics could account for the observed differences in the countries of Latin America. In Argentina, for example, the population is predominantly Caucasian, whereas in Colombia and Ecuador, it is predominately mestizo. This may partially explain the higher risk for MS in the southern part of the continent when compared with the central region. ${ }^{7}$

\section{Current disease-modifying therapies for multiple sclerosis in Argentina}

Treatment options mainly tend to halt or slow the progression of disability as well as provide a reduction in the relapse rate of affected patients. ${ }^{13}$

The current treatment options available in Argentina are discussed here (Tables 1 and 2).

\section{Interferon beta}

Interferon beta (IFN beta) has been demonstrated to be effective in controlling disease activity in MS, but the precise mechanism of action of IFN beta remains to be defined. Its anti-inflammatory activity in MS is dominated by antiproliferative and proapoptotic effects via molecular changes that include the expression of Fas/Fas ligand, p53,

Table I Current and emerging disease modifying drugs in Argentina*

\begin{tabular}{lll}
\hline DMD & Status & $\begin{array}{l}\text { Year of approval } \\
\text { in Argentina }\end{array}$ \\
\hline IFN beta-Ib subcutaneously & Available & 1995 \\
IFN beta-Ia intramuscularly & Available & 1996 \\
IFN beta-Ia subcutaneously & Available & 1997 \\
Glatiramer acetate & Available & 1997 \\
Natalizumab & Available & 2010 \\
Fingolimod & Available & 2011 \\
Teriflunomide & Available & 2013 \\
Alemtuzumab & Under evaluation & - \\
BG-I2 & Under evaluation & - \\
\hline
\end{tabular}

Note: *Information collected in December 2013. 
Table 2 Current approved disease-modifying drugs in relapsing multiple sclerosis in Argentina

\begin{tabular}{|c|c|c|c|c|c|}
\hline \multirow{2}{*}{$\begin{array}{l}\text { Agent (route } \\
\text { and frequency } \\
\text { of administration) }\end{array}$} & \multirow[t]{2}{*}{ Trade name (company) } & \multicolumn{4}{|c|}{ Effect on disease activity relative to placebo } \\
\hline & & Relapse rate & $\begin{array}{l}\text { MRI active } \\
\text { lesions }\end{array}$ & $\begin{array}{l}\text { Confirmed EDSS } \\
\text { progression* }\end{array}$ & $\begin{array}{l}\text { Change in T2 } \\
\text { lesion volume }\end{array}$ \\
\hline $\begin{array}{l}\text { IFN beta-Ib } \\
\text { (subcutaneous injection } \\
\text { every other day) }{ }^{20}\end{array}$ & $\begin{array}{l}\text { Betaferon }^{\circledast} \text { (Schering, Berlin, } \\
\text { Germany); Betaseron }{ }^{\circledast} \text { (Bayer, } \\
\text { Leverkusen, Germany); Extavia } \\
\text { (Novartis, Basel, Switzerland) }\end{array}$ & $\begin{array}{l}\text { Annualized, } \\
-34 \%(P=0.0001)\end{array}$ & $-83 \%(P<0.009)$ & $-29 \%$ (not significant) & $-17.3 \%(P=0.001)$ \\
\hline $\begin{array}{l}\text { IFN beta-Ia } \\
\text { (intramuscular injection } \\
\text { once a week) }{ }^{21}\end{array}$ & $\begin{array}{l}\text { Avonex }{ }^{\circledR} \text { (Biogen Idec, } \\
\text { Weston, MA, USA) }\end{array}$ & $\begin{array}{l}\text { Annualized, } \\
-32 \%(P \leq 0.04)\end{array}$ & $-36 \%(P=0.05)$ & $-37 \%(P=0.02)$ & $-4 \%$ (not significant) \\
\hline $\begin{array}{l}\text { IFN beta-Ia } \\
\text { (subcutaneous injection, } \\
\text { three times a week) }{ }^{23}\end{array}$ & $\begin{array}{l}\text { Rebif }^{\circledast} \text { (EMD Serono/Pfizer, } \\
\text { Darmstadt, Germany) }\end{array}$ & $\begin{array}{l}\text { Mean, } \\
-32 \%(P<0.005)\end{array}$ & $-78 \%(P<0.000 I)$ & $-30 \%(P<0.05)$ & $-14.7 \%(P<0.000 \mid)$ \\
\hline $\begin{array}{l}\text { Glatiramer acetate } \\
\text { (subcutaneous injection, } \\
\text { daily) }\end{array}$ & $\begin{array}{l}\text { Copaxone }^{\circledR} \\
\text { (Teva Pharmaceuticals, } \\
\text { Petah Tikva, Israel) }\end{array}$ & $\begin{array}{l}\text { Mean, } \\
-29 \%(P=0.007)\end{array}$ & $-35 \%(P<0.00 I)$ & $-12 \%$ (not significant) & $-8.3 \%(P=0.001 \mathrm{I})$ \\
\hline $\begin{array}{l}\text { Natalizumab } \\
\text { (intravenous infusion } \\
\text { every } 4 \text { weeks) }\end{array}$ & $\begin{array}{l}\text { Tysabri® (Biogen Idec, Weston, } \\
\text { MA, USA/Elan Pharmaceuticals, } \\
\text { Dublin, Ireland) }\end{array}$ & $\begin{array}{l}\text { Annualized, } \\
-68 \%(P<0.00 \mathrm{I})\end{array}$ & $-83 \%(P<0.0001)$ & $-42 \%(P<0.00 \mathrm{I})$ & $-18 \%(P<0.001)$ \\
\hline $\begin{array}{l}\text { Fingolimod (daily pill, } \\
0.5 \mathrm{mg} \text { ) }\end{array}$ & Gilenya ${ }^{\circledR}$ (Novartis) & $\begin{array}{l}\text { Annualized, } \\
-54 \%(P<0.00 \mathrm{I})\end{array}$ & $-82 \%(P<0.000 \mathrm{I})$ & $-37 \%(P<0.05)$ & $-69 \%(P<0.000 I)$ \\
\hline 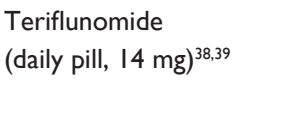 & $\begin{array}{l}\text { Aubagio }^{\circledR} \text { (Genzyme, } \\
\text { Cambridge, MA, USA/Sanofi, } \\
\text { Paris, France) }\end{array}$ & $\begin{array}{l}\text { Annualized, } \\
-31.5 \%(P<0.001)\end{array}$ & $-80 \%(P<0.00 \mathrm{I})$ & $-29.8 \%(P=0.03)$ & $-76.7 \%(P<0.00 I)$ \\
\hline
\end{tabular}

Note: *Definitions for EDSS progression varied slightly across studies.

Abbreviations: EDSS, expanded disability status scale; MRI, magnetic resonance imaging.

and Bax (proapoptotic molecules), as well as inhibition of the production of proinflammatory cytokines such as interleukin 1 (IL-1) and tumor necrosis factor. ${ }^{14}$ IFN beta also has shown a decrease in the production of IL-23 and increased IL-10 production by dendritic cells. The molecule also modified the production of IL-17 via dendritic cells..$^{15}$ Through these anti-inflammatory activities, IFN beta controls disease activity in MS patients. ${ }^{14-18}$ Subcutaneous IFN beta- $1 \mathrm{~b}$ was studied in RRMS patients in a randomized, double-blind, placebocontrolled study in $1993 .{ }^{19,20}$ The study demonstrated that the relapse rate for patients receiving placebo was 1.27 ; for those receiving 1.6 million units, it was 1.17; and for those receiving 8 million units IFN beta- $1 \mathrm{~b}$, it was 0.84 after 2 years. Two years later, Jacobs et al studied the efficacy of IFN beta-1a administered intramuscularly in a multicenter, randomized, placebo-controlled study. ${ }^{21}$ A significant delay in time to sustained EDSS progression $(-37 \% ; P=0.02)$ was observed, as well as significantly fewer exacerbations $(P=0.03)$ in patients treated with IFN versus those in the placebo group. Finally, in 1998, a randomized, multicenter, double-blind, placebocontrolled study evaluated the efficacy of IFN beta-1a given subcutaneously versus placebo in RRMS. ${ }^{22,23}$ The relapse rate was significantly lower with the doses of IFN beta (44 and 22 $\mu \mathrm{g})$ compared with placebo, with a risk reduction of relapses of $27 \%$ for $22 \mu \mathrm{g}$ (95\% confidence interval, $14 \%-39 \%)$ and
$33 \%$ for $44 \mu \mathrm{g}$ (95\% confidence interval, $21-44){ }^{22,23}$ Adverse effects of IFN beta therapy include influenza-like symptoms (fevers, chills, and myalgias) and mild abnormalities on routine laboratory evaluation, such as an elevation in liver enzymes or mild lymphopenia. ${ }^{22,23}$ Rarely, severe hepatotoxicity and muscle abscesses associated with intramuscular application have been reported. When injected subcutaneously, IFN beta also often causes reactions at the site of injection, including pain, redness, induration, or rarely, skin necrosis.

In Argentina, available formulations of IFN beta approved to treat MS include the three original IFN beta formulations (subcutaneous IFN beta-1a, Rebif ${ }^{\circledR}$ [EMD Serono/Pfizer, Darmstadt, Germany]; subcutaneous IFN beta-1b, Betaferon ${ }^{\circledR}$ [Schering, Berlin, Germany]/Betaseron ${ }^{\circledR}$ [Bayer, Leverkusen, Germany]; and intramuscular IFN beta-1a, Avonex ${ }^{\circledR}$ [Biogen Idec, Weston, MA, USA]), which have been available in Argentina since 1997 for the treatment of RRMS patients, and two biosimilar formulations (subcutaneous IFN beta-1a Blastoferon ${ }^{\circledR}$ [Farmacias Ahumada, Santiago, Chile] and Inmunomas ${ }^{\circledR}$ [AMEGA biotech, San Isidro, Argentina], available since 2005 and 2011, respectively).

\section{Glatiramer acetate}

Glatiramer acetate (GA) is a synthetic copolymer made up of four amino acids (L-glutamic acid, L-lysine, L-alanine, and 
L-tyrosine). ${ }^{19}$ Molecular research has shown that GA could act by a direct mechanism to control immunological activity in MS patients. GA is processed by antigen-presenting cells. Through class I and class II presentation pathways, GA is later presented to cluster of differentiation (CD) $8+$ and CD4+ $\mathrm{T}$ cells. A CD8+ T-cell response results in modification of antigen-presenting cell subsets. ${ }^{24}$ Presentation by modified antigen-presenting cells subsequently results in the generation of CD4+ T-regulatory cells, a direct killing of Th1 CD4+ $\mathrm{T}$ cells, and deviation toward Th2 response involved in the immunological regulation achieved in MS patients with GA. ${ }^{24-26}$ A multicenter, randomized, double-blind, placebocontrolled trial evaluated the efficacy of GA in RRMS. A relapse rate of more than 2 years was significantly reduced in patients under GA versus placebo $(1.19 \pm 0.13$ versus $1.68 \pm 0.13 ;-29 \% ; P=0.007) .{ }^{26}$ Adverse effects of GA include injection-site reactions (eg, pain, redness, and induration), although these are generally mild. A few patients treated with GA in the pivotal trial (15.2\%) experienced an immediate postinjection reaction, which consists of flushing and/or chest pain together with a variable secondary symptom complex including palpitations, anxiety, and/or dyspnea. ${ }^{26}$

In Argentina, available formulations of GA approved in the treatment of MS include the original form of Copaxone ${ }^{\circledR}$ (Teva Pharmaceuticals, Petah Tikva, Israel), available for use in Argentina since 1997 for the treatment of RRMS patients, and Escadra ${ }^{\circledR}$ (MR PHARMA S.A., Buenos Aires, Argentina), a biosimilar formulation of GA available since 2012.

\section{Natalizumab}

Natalizumab is a humanized monoclonal antibody that is directed against the $\alpha 4 \beta 1$-integrin molecule on mononuclear white blood cells, including lymphocytes. ${ }^{27}$ In the Phase III trial of natalizumab versus placebo (Natalizumab Safety and Efficacy in Relapsing Remitting Multiple Sclerosis [AFFIRM] study), ${ }^{28}$ there was a $67 \%$ decrease in relapse rate and a $50 \%$ reduction in the accumulation of persistent new disability in the natalizumab-treated group. A post hoc analysis of that study focusing on a stringent definition of disease-free activity (a composite of the absence of activity in clinical aspects, plus absence of activity on magnetic resonance image measures) yielded proportions of $37 \%$ (natalizumab) versus $7 \%$ (placebo). ${ }^{29}$ Natalizumab was withdrawn after two cases of progressive multifocal leukoencephalopathy (PML) in the extension phase of the Safety and Efficacy of Natalizumab in Combination with IFN beta-1a in Patients with Relapsing Remitting Multiple Sclerosis (SENTINEL) study and then reintroduced after the establishment of intensive surveillance regimens with long-term safety data reporting. ${ }^{30}$ Real-world data demonstrated that being able to stratify John Cunningham virus (JCV) status was useful in stratifying the risk of PML. If negative, PML is unlikely to occur (although it is not impossible). ${ }^{31}$ Nearly 6,000 patients from the AFFIRM, Tysabri ${ }^{\circledR}$ Global Observation Program in Safety-US, JCV Antibody Program in Patients with Relapsing Multiple Sclerosis Receiving or Considering Treatment with Tysabri (STRATIFY-1), and the Swedish MS registries had baseline blood samples available for anti-JCV antibody testing to stratify the risk of PML in patients treated with natalizumab. ${ }^{32}$

In Argentina, the STRATIFY program is currently available for the follow-up of MS patients under natalizumab to identify the presence of anti-JCV and the titers, if present, in order to stratisfy the risk of PML.

Tysabri $^{\circledR}$ (natalizumab; Biogen Idec, Weston, MA, USA/ Elan Pharmaceuticals, Dublin, Ireland) was approved in Argentina by local authorities in 2010 and has been available for the treatment of MS patients since then.

\section{Fingolimod}

Fingolimod is an oral sphingosine 1-phosphate receptor modulator that was approved for the treatment of MS in 2010 in North America and 2011 in Europe. ${ }^{33,34}$ Its mechanism of action is thought to be through an active phosphorylated metabolite, FTY720-P, which resembles sphingosine 1-phosphate and alters lymphocyte trafficking through receptor subtype sphingosine 1-phosphate $1 .{ }^{35}$ The consequent molecular process modulates the actin cytoskeleton of cells, thereby affecting pseudopodia formation and the migration of lymphocytes, process outgrowth, endothelial cell migration, angiogenesis, and endothelial permeability barriers. ${ }^{35}$ Phase III clinical trial results with fingolimod have demonstrated efficacy in patients with RRMS. The 12-month, double-blind trial assessing injectable IFN beta-1a (30 mg/week) versus fingolimod (o,5 or $1.25 \mathrm{mg} /$ day) in RRMS (TRANSFORMS trial), showed an annualized relapse rate (ARR) of 0.16 for $0.5 \mathrm{mg}$ /day fingolimod, 0.20 for $1.25 \mathrm{mg} /$ day fingolimod, and 0.33 for IFN beta- $1 \mathrm{a}$ $(P<0.001$ for each fingolimod dose versus IFN beta-1a). The Phase III Efficacy and Safety of Fingolimod in Patients With Relapsing-remitting Multiple Sclerosis (FREEDOMS) trial was a 24-month, double-blind, randomized study that included 1,272 patients with RRMS. ${ }^{36}$ The ARR was 0.18 for $0.5 \mathrm{mg} /$ day fingolimod, 0.16 for $1.25 \mathrm{mg}$ /day fingolimod, and 0.40 for placebo $(P<0.001$ for each dose versus placebo). In this study, fingolimod also decreased the risk for disability progression (hazard ratio, $0.70 ; 95 \%$ confidence interval for $0.5 \mathrm{mg} /$ day fingolimod). Main adverse events 
in Phase III clinical trials with fingolimod were related to the bradycardia induced during the first 6 hours of the first intake of medication that led to the implementation of blood pressure and heart rate monitoring in all patients in Argentina during this period. Other related adverse events included headache, macular edema in patients with history of diabetes and uveitis, and lower respiratory tract infections. ${ }^{33,36}$

In Argentina, Gilenya ${ }^{\circledR}$ (fingolimod; Novartis, Basel, Switzerland) was approved in April 2011.

\section{Teriflunomide}

Teriflunomide is an oral reversible inhibitor of dihydroorotate dehydrogenase, a mitochondrial membrane protein essential to pyrimidine synthesis. ${ }^{37}$ Dihydro-orotate dehydrogenase blocks de novo pyrimidine synthesis, leading to an inhibition of the proliferation of autoreactive $\mathrm{B}$ and $\mathrm{T}$ cells. ${ }^{37}$ The Phase III clinical Teriflunomide Multiple Sclerosis Oral (TEMSO) study $^{38}$ demonstrated a significant reduction in ARR and disability progression with teriflunomide compared with placebo. Patients in the study were randomized to teriflunomide 7 or $14 \mathrm{mg}$ /day or placebo. The adjusted ARRs with teriflunomide at 7 and $14 \mathrm{mg} /$ day were 0.370 and 0.369 , respectively, compared with 0.539 for placebo $(P<0.001$ for both comparisons). The $14 \mathrm{mg}$ /day dose of teriflunomide was associated with a $29.8 \%$ reduction in the risk for sustained disability progression $(P=0.028)$. Two additional studies, the Teriflunomide Oral in People with Relapsing-Remitting Multiple Sclerosis (TOWER) ${ }^{39}$ and a Study Comparing the Effectiveness and Safety of Teriflunomide and IFN beta-1a in Patients with Relapsing Multiple Sclerosis compared teriflunomide with placebo and IFN beta-1a $44 \mu \mathrm{g}$ subcutaneous, respectively. ${ }^{40}$ Both studies showed that teriflunomide 7 and $14 \mathrm{mg}$ was superior to placebo in reducing ARRs, but no differences were found between teriflunomide and IFN beta-1a subcutaneous $44 \mu \mathrm{g}$ regarding ARRs. Main adverse events reported were an increase of liver enzymes, neutropenia, rhabdomyolysis, and trigeminal neuralgia.

Aubagio $^{\circledR}$ (teriflunomide; Genzyme, Cambridge, MA, USA/Sanofi, Paris, France) was approved for use in Argentina in March 2013 and is currently available to treat RRMS.

\section{Emerging disease-modifying therapies for multiple sclerosis in Argentina Alemtuzumab}

Alemtuzumab is a humanized monoclonal antibody against CD52, a glycoprotein antigen found on the surface of mature lymphocytes and monocytes. ${ }^{41}$ Its mechanism of action is thought to be mediated by prolonged T-cell depletion and modulation of the lymphocyte repertoire caused by pulsed administration of the medication. Specifically, a distinctive pattern of T- and B-cell repopulation begins within weeks of administration, leading to a change in the balance of the immune system. Alemtuzumab was studied in a Phase II Study Comparing Low- and High-Dose Alemtuzumab and High-Dose Rebif ${ }^{\circledR}$ in Patients With Early, Active RelapsingRemitting Multiple Sclerosis (CAMMS223), a 3-year, Phase II, rater-blinded trial. The patients were randomized to subcutaneous IFN beta-1a (44 mg three times per week) or annual intravenous cycles of alemtuzumab (12 or $24 \mathrm{mg} /$ day) for 36 months. ${ }^{42}$ Alemtuzumab was associated with a significantly reduced rate of sustained disability accumulation versus IFN beta-1a $(9.0 \%$ versus $26.2 \% ; P<0.001)$. The mean EDSS score improved by 0.39 points with alemtuzumab and worsened by 0.38 points with IFN beta-1a $(P<0.001)$. Two Phase III trials of alemtuzumab (Comparison of Alemtuzumab and Rebif ${ }^{\circledR}$ Efficacy in Multiple Sclerosis I [CARE-MS I] and Comparison of Alemtuzumab and Rebif ${ }^{\circledR}$ Efficacy in Multiple Sclerosis II [CARE-MS II]) were recently presented. CARE-MS I compared alemtuzumab (12 mg/day for 5 days initially and for 3 days the year after) versus subcutaneous IFN beta-1a (44 mg three times per week) in patients with RRMS who had not received prior disease-modifying therapy. This study showed that alemtuzumab resulted in a 55\% reduction in relapse rate versus IFN beta-1a over the course of 2 years $(P<0.0001) .{ }^{43}$ CARE-MS II compared alemtuzumab with IFN beta-1a subcutaneously in patients with RRMS who relapsed on prior therapy. The study showed a $49 \%$ reduction in relapse rate in patients receiving alemtuzumab $12 \mathrm{mg}$ compared with IFN beta-1a subcutaneously $(P<0.0001) .{ }^{43}$ The coprimary end point showed a $42 \%$ reduction in the risk for sustained disability measured by $\operatorname{EDSS}(P=0.008)$. The main adverse events reported included thyroid disorders $(23 \%$ versus $3 \%$ ), immune thrombocytopenic purpura (3\% versus $1 \%$ ), and infections ( $66 \%$ versus $47 \%) .{ }^{42}$

Currently, Lemtrada (alemtuzumab; Genzyme, Cambridge, MA, USA) is under consideration for approval in Argentina, and a compassionate program is under use to provide MS patients with alemtuzumab.

\section{BG-I 2 (dimethyl fumarate)}

BG-12 is a fumaric acid ester with immunomodulatory properties. It produces a decrease in leukocyte passage through the blood-brain barrier, causing a neuroprotective effect by the activation of antioxidative pathways. ${ }^{44}$

Determination of the Efficacy and Safety of Oral Fumarate in RRMS (DEFINE) was a Phase III, randomized, 
double-blind, placebo-controlled, dose-comparison study of BG-12 in 1,234 RRMS patients. ${ }^{45}$ Patients were randomized either to BG-12 at a dose of either $240 \mathrm{mg} /$ twice a day or $240 \mathrm{mg} /$ three times a day or to placebo. Both BG-12 doses were associated with a significant decrease in the proportion of patients who relapsed at 2 years compared with placebo $(P<0.0001)$. Both BG-12 doses were significantly superior to placebo in reducing ARR and were also superior to placebo in slowing the rate of disability progression, as measured by EDSS scores at 2 years. Results were observed in a second randomized, double-blind, placebo-controlled trial with placebo and a comparative group of GA. ${ }^{45}$

Main adverse events occurring more often with BG-12 versus placebo were abdominal pain, flushing, and hot flush. ${ }^{45}$ BG-12 has been approved and is currently in use for RRMS patients in the United States.

In Argentina, Tecfidera ${ }^{\circledR}$ (BG-12; Biogen Idec) is under consideration for approval to treat of RRMS patients.

Laquinimod and monoclonal antibodies such as rituximab, daclizumab, ocrelizumab, and ofatumumab are completing Phase III clinical trials; results are therefore expected to undergo regulatory evaluation in Argentina.

\section{Conclusion}

Argentina is a medium-risk country for MS, with a prevalence estimated at 12-20 cases per 100,000 inhabitants and an incidence of 1.7 cases per 100,000 inhabitants per year. Current and emerging disease-modifying treatments for MS are available to treat MS patients in Argentina to obtain freedom from disease and improve long-term outcomes. Physicians should be aware of their efficacy and safety profiles to be able to choose the best treatment option for each patient, according to the presentation and progression of the disease.

\section{Disclosure}

JIR has received honoraria from Novartis as a scientific advisor and has received travel grants and attended courses and conferences on behalf of Merck-Serono Argentina and Novartis Argentina. LP has received honoraria for scientific and research grants from Teva Tuteur, Merck Serono, Biogen Idec, and Bayer Schering. EC has received fees for consultations as a scientific advisory board member and for travel to meetings, conferences, and clinical trials from Avanir, Bayer, Biogen, Merck, Novartis, and Teva. The authors declare no other conflicts of interest.

\section{References}

1. Noseworthy JH, Lucchinetti C, Rodriguez M, Weinshenker BG. Multiple sclerosis. N Engl J Med. 2000;343(13):938-952.
2. Simmons RD. Life issues in multiple sclerosis. Nat Rev Neurol. 2010;6(11):603-610.

3. Cristiano E, Patrucco L, Rojas JI. A systematic review of the epidemiology of multiple sclerosis in South America. Eur J Neurol. 2008;15(12): $1273-1278$

4. Cristiano E, Patrucco L, Rojas JI, et al. Prevalence of multiple sclerosis in Buenos Aires, Argentina using the capture-recapture method. Eur $J$ Neurol. 2009;16(2):183-187.

5. El sistema de salud en Argentina. 2002. 2014. Available from: http:// www.bibleduc.gov.ar/areas/salud/dircap/mat/matbiblio/salud.pdf. Accessed November 22, 2013.

6. Administración Nacional de Medicamentos, Alimentos y Tecnología Médica (ANMAT). Available from: http://www.anmat.gov.ar/principal. asp. Accessed November 22, 2013.

7. Cristiano E, Rojas J, Romano M, et al. The epidemiology of multiple sclerosis in Latin America and the Caribbean: a systematic review. Mult Scler. 2013;19(7):844-854.

8. Patrucco L, Larriba J, Redal MA, Rojas JI, Argibay PF, Cristiano E. HLA-DRB1 and multiple sclerosis in Argentina. Eur J Neurol. 2009; 16(3):427-429.

9. Melcon MO, Gold L, Carrá A, et al; Patagonia Multiple Sclerosis Research Project. Argentine Patagonia: prevalence and clinical features of multiple sclerosis. Mult Scler. 2008;14(5):656-662.

10. Cristiano E, Patrucco L, Soriano E, Videla G, Hares D, Bauzo T. Incidence and prevalence of Multiple Sclerosis in an HMO in Argentina. Mult Scl. 2002;8:36.

11. Rojas JI, Patrucco L, Cristiano E. [Multiple sclerosis in Argentina. Systematic review and meta-analysis]. Medicina (B Aires). 2012;72(6): 449-454. Spanish.

12. Ysrraelit C, Caceres F, Villa A, et al. ENCOMS: Argentinian Survey in Cost of Illness and Unmet Needs in Multiple Sclerosis. Program and abstracts of the European Committee for Treatment and Research in Multiple Sclerosis; October 10-13; 2012, Lyon, France.

13. Cohen BA, Khan O, Jeffery DR, et al. Identifying and treating patients with suboptimal responses. Neurology. 2004;63(12 Suppl 6): S33-S40.

14. Guarda G, Braun M, Staehli F, et al. Type I interferon inhibits interleukin-1 production and inflammasome activation. Immunity. 2011;34(2):213-223.

15. Sweeney CM, Lonergan R, Basdeo SA, et al. IL-27 mediates the response to IFN- $\beta$ therapy in multiple sclerosis patients by inhibiting Th17 cells. Brain Behav Immun. 2011;25(6):1170-1181.

16. Yong VW. Differential mechanisms of action of interferon-beta and glatiramer aetate in MS. Neurology. 2002;59(6):802-808.

17. Yong VW, Chabot S, Stuve O, Williams G. Interferon beta in the treatment of multiple sclerosis: mechanisms of action. Neurology. 1998;51(3):682-689.

18. Yen JH, Kong W, Ganea D. IFN-beta inhibits dendritic cell migration through STAT-1-mediated transcriptional suppression of CCR7 and matrix metalloproteinase 9. J Immunol. 2010;184(7):3478-3486.

19. Paty DW, Li DK. Interferon beta-1b is effective in relapsing-remitting multiple sclerosis. II. MRI analysis results of a multicenter, randomized, double-blind, placebo-controlled trial. UBC MS/MRI Study Group and the IFNB Multiple Sclerosis Study Group. Neurology. 1993;43(4): 662-667.

20. Interferon beta- $1 \mathrm{~b}$ is effective in relapsing-remitting multiple sclerosis. I. Clinical results of a multicenter, randomized, double-blind, placebocontrolled trial. The IFNB Multiple Sclerosis Study Group. Neurology. 1993;43(4):655-661.

21. Jacobs LD, Cookfair DL, Rudick RA, et al. Intramuscular interferon beta-1a for disease progression in relapsing multiple sclerosis. The Multiple Sclerosis Collaborative Research Group (MSCRG). Ann Neurol. 1996;39(3):285-294.

22. Hicks A. Interferon beta- $1 \mathrm{~b}$ in the treatment of multiple sclerosis: final outcome of the randomized controlled trial. The IFNB Multiple Sclerosis Study Group and The University of British Columbia MS/MRI Analysis Group. Neurology. 1995;45(7):1277-1285. 
23. Hicks A. Randomised double-blind placebo-controlled study of interferon beta-1a in relapsing/remitting multiple sclerosis. PRISMS (Prevention of Relapses and Disability by Interferon beta-1a Subcutaneously in Multiple Sclerosis) Study Group. Lancet. 1998;352(9139):1498-1504.

24. Racke MK, Lovett-Racke AE. Glatiramer acetate treatment of multiple sclerosis: an immunological perspective. J Immunol. 2011;186(4): 1887-1890.

25. Farina C, Weber MS, Meinl E, Wekerle H, Hohlfeld R. Glatiramer acetate in multiple sclerosis: update on potential mechanisms of action. Lancet Neurol. 2005;4(9):567-575.

26. Johnson KP, Brooks BR, Cohen JA, et al. Copolymer 1 reduces relapse rate and improves disability in relapsing-remitting multiple sclerosis: results of a phase III multicenter, double-blind placebo-controlled trial. The Copolymer 1 Multiple Sclerosis Study Group. Neurology. 1995;45(7):1268-1276.

27. Elices MJ, Osborn L, Takada Y, et al. VCAM-1 on activated endothelium interacts with the leukocyte integrin VLA-4 at a site distinct from the VLA-4/fibronectin binding site. Cell. 1990;60(4):577-584.

28. Polman CH, O’Connor PW, Havrdova E, et al; AFFIRM Investigators A randomized, placebo-controlled trial of natalizumab for relapsing multiple sclerosis. N Engl J Med. 2006;354(9):899-910.

29. Havrdova E, Galetta S, Hutchinson M, et al. Effect of natalizumab on clinical and radiological disease activity in multiple sclerosis: a retrospective analysis of the Natalizumab Safety and Efficacy in Relapsing-Remitting Multiple Sclerosis (AFFIRM) study. Lancet Neurol. 2009;8(3):254-260.

30. Rudick RA, Stuart WH, Calabresi PA, et al; SENTINEL Investigators Natalizumab plus interferon beta-1a for relapsing multiple sclerosis. N Engl J Med. 2006;354(9):911-923.

31. Gorelik L, Lerner M, Bixler S, et al. Anti-JC virus antibodies: implications for PML risk stratification. Ann Neurol. 2010;68(3):295-303.

32. Bloomgren G, Richman S, Hotermans C, et al. Risk of natalizumabassociated progressive multifocal leukoencephalopathy. $N$ Engl J Med. 2012;366(20):1870-1880.

33. Cohen JA, Barkhof F, Comi G, et al; TRANSFORMS Study Group. Oral fingolimod or intramuscular interferon for relapsing multiple sclerosis. N Engl J Med. 2010;362(5):402-415.

34. Kowarik MC, Pellkofer HL, Cepok S, et al. Differential effects of fingolimod (FTY720) on immune cells in the CSF and blood of patients with MS. Neurology. 2011;76(14):1214-1221.
35. Brinkmann V, Billich A, Baumruker T, et al. Fingolimod (FTY720): discovery and development of an oral drug to treat multiple sclerosis. Nat Rev Drug Discov. 2010;9(11):883-897.

36. Kappos L, Radue EW, O'Connor P, et al; FREEDOMS Study Group. A placebo-controlled trial of oral fingolimod in relapsing multiple sclerosis. N Engl J Med. 2010;362(5):387-401.

37. Palmer AM. Teriflunomide, an inhibitor of dihydroorotate dehydrogenase for the potential oral treatment of multiple sclerosis. Curr Opin Investig Drugs. 2010;11(11):1313-1323.

38. O'Connor P, Wolinsky JS, Confavreux C, et al. Randomized trial of oral teriflunomide for relapsing multiple sclerosis. $N$ Engl J Med. 2011;365(14):1293-1303.

39. Confavreux C, O’Connor P, Comi G, et al; TOWER Trial Group. Oral teriflunomide for patients with relapsing multiple sclerosis (TOWER): a randomised, double-blind, placebo-controlled, phase 3 trial. Lancet Neurol. 2014;13(3):247-256.

40. Sanofi. Efficacy and safety of teriflunomide in patients with relapsing multiple sclerosis and treated with interferon-beta (TERACLES). Available from: http:/clinicaltrials.gov/ct2/show/NCT01252355. NLM identifier: NCT01252355. Accessed February 13, 2013.

41. Hu Y, Turner MJ, Shields J, et al. Investigation of the mechanism of action of alemtuzumab in a human CD52 transgenic mouse model. Immunology. 2009;128(2):260-270.

42. CAMMS223 Trial Investigators, Coles AJ, Compston DA, et al. Alemtuzumab vs. interferon beta-1a in early multiple sclerosis. $N$ Engl J Med. 2008;359(17):1786-1801.

43. Coles AJ, Brinar V, Arnold DL, et al. Efficacy and safety results from CARE-MS I: a phase 3 study comparing alemtuzumab and interferonbeta-1a. In: Program and abstracts of the 5th Joint Triennial Congress of the European and Americas Committees for Treatment and Research in Multiple Sclerosis (ECTRIMS/ACTRIMS); October 19-22; 2011; Amsterdam, The Netherlands.

44. Lee DH, Linker RA, Gold R. Spotlight on fumarates. Int MS J. 2008;15(1):12-18

45. Gold R, Kappos L, Bar-Or D. Clinical efficacy of BG-12, an oral therapy, in relapsing-remitting multiple sclerosis: data from the phase 3 DEFINE trial. In: Program and abstracts of the 5th Joint Triennial Congress of the European and Americas Committees for Treatment and Research in Multiple Sclerosis (ECTRIMS/ACTRIMS); October 19-22; 2011; Amsterdam, The Netherlands.
Degenerative Neurological and Neuromuscular Disease

\section{Publish your work in this journal}

Degenerative Neurological and Neuromuscular Disease is an international, peer-reviewed, open access journal focusing on research into degenerative neurological and neuromuscular disease, identification of therapeutic targets and the optimal use of preventative and integrated treatment interventions to achieve improved outcomes, enhanced

\section{Dovepress}

survival and quality of life for the patient. The manuscript management system is completely online and includes a very quick and fair peer-review system. Visit http://www.dovepress.com/testimonials.php to read real quotes from published authors. 